\title{
Phycicoccus aerophilus sp. nov., isolated from air
}

Correspondence

Soon-Wo Kwon

swkwon@rda.go.kr

\author{
Hang-Yeon Weon, ${ }^{1}$ Seung-Hee Yoo, ${ }^{2}$ Byung-Yong Kim, ${ }^{2}$ \\ Peter Schumann, ${ }^{3}$ Reiner M. Kroppenstedt, ${ }^{3}$ Sung-Kee Hong ${ }^{4}$ \\ and Soon-Wo Kwon ${ }^{2}$
}

\author{
${ }^{1}$ Applied Microbiology Division, National Institute of Agricultural Science and Technology, Rural \\ Development Administration, Suwon 441-707, Republic of Korea \\ ${ }^{2}$ Korean Agricultural Culture Collection (KACC), Microbial Genetics Division, National Institute of \\ Agricultural Biotechnology, Rural Development Administration, Suwon 441-707, Republic of Korea \\ ${ }^{3} \mathrm{DSMZ}$ - Deutsche Sammlung von Mikroorganismen und Zellkulturen GmbH, Inhoffenstraße 7b, \\ D-38124 Braunschweig, Germany \\ ${ }^{4}$ Plant Pathology Division, National Institute of Agricultural Science and Technology, Rural \\ Development Administration, Suwon 441-707, Republic of Korea
}

\begin{abstract}
A Gram-positive, short rod-shaped, non-spore-forming bacterium, designated $5516 \mathrm{~T}-20^{\top}$, was isolated from an air sample. The results of $16 \mathrm{~S}$ rRNA gene sequence analyses showed that strain $5516 \mathrm{~T}-20^{\top}$ belonged to the family Intrasporangiaceae, having the highest sequence similarities (97.5 and $96.1 \%$, respectively) with respect to the type strains of Phycicoccus dokdonensis and Phycicoccus jejuensis. The value for DNA-DNA hybridization between 5516T-20 ${ }^{\top}$ and $P$. dokdonensis DS-8 ${ }^{\top}$ was $41 \%$. Strain $5516 \mathrm{~T}-20^{\top}$ contained menaquinone $\mathrm{MK}-8\left(\mathrm{H}_{4}\right)$ as the major isoprenoid quinone, possessed phosphatidylethanolamine, phosphatidylinositol and diphosphatidylglycerol as the polar lipids and contained glucose and ribose as whole-cell sugars. The major fatty acids were $C_{17: 1} \omega 8 c$, iso- $C_{16: 0}$, iso- $C_{15: 0}, C_{17: 0}$ and iso- $C_{14: 0}$. The $G+C$ content of the DNA from strain $5516 \mathrm{~T}-20^{\top}$ was $70.5 \mathrm{~mol} \%$. On the basis of the data from the polyphasic taxonomic study, strain $5516 \mathrm{~T}-20^{\top}$ represents a novel species within the genus Phycicoccus, for which the name Phycicoccus aerophilus sp. nov. is proposed. The type strain is

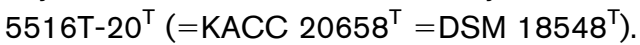

The genus Phycicoccus was described by Lee (2006) with a single species, Phycicoccus jejuensis. Recently, the species Phycicoccus dokdonensis was added to the genus (Yoon et al., 2008). The genus Phycicoccus includes Gram-positive, coccus-shaped bacteria with meso-diaminopimelic acid as the diamino acid of the peptidoglycan, $\mathrm{MK}-8\left(\mathrm{H}_{4}\right)$ as the predominant menaquinone and $\mathrm{C}_{17: 1} \omega 8 c$, iso- $\mathrm{C}_{16: 0}$, iso$\mathrm{C}_{15: 0}, \mathrm{C}_{15: 0}$ and $\mathrm{C}_{17: 0}$ as the major fatty acids. Phylogenetically, the genus belongs to the family Intrasporangiaceae, suborder Micrococcineae (Stackebrandt et al., 1997).

Strain $5516 \mathrm{~T}-20^{\mathrm{T}}$ was isolated during the characterization of bacterial strains isolated from air collected with an air sampler (single-stage, multiple-hole impactor, MAS-100; Merck) in the Taean region of the Republic of Korea. The sampler contained Petri dishes with R2A agar (BBL) amended with $0.02 \%$ cycloheximide (Sigma). After sampling, the plates were incubated at $30{ }^{\circ} \mathrm{C}$ for 5 days.

The GenBank/EMBL/DDBJ accession number for the 16S rRNA gene sequence of strain $5516 \mathrm{~T}-20^{\top}$ is EF493847.

Cellular fatty acid profiles of strain $5516 \mathrm{~T}-20^{\top}$ and related strains are available as supplementary material with the online version of this paper.
Strain $5516 \mathrm{~T}-20^{\mathrm{T}}$ produced white-coloured colonies on R2A medium. The strain was found to be able to grow on nutrient agar and tryptic soy agar, but not on MacConkey agar (all from Difco).

For the phenotypic characterization, R2A medium was used as the basal medium. Gram staining, catalase and oxidase activities and hydrolysis of casein, CM-cellulose, chitin, DNA, hypoxanthine, pectin, starch, Tween 80, tyrosine and xanthine were determined using the methods of Smibert \& Krieg (1994). Temperature, salinity and $\mathrm{pH}$ for growth were tested at $5,10,20,25,30,37,40$ and $45{ }^{\circ} \mathrm{C}$, at $0,1,3,5,7$ and $10 \%(\mathrm{w} / \mathrm{v}) \mathrm{NaCl}$ and at $\mathrm{pH} 4,5,6,7,8,9$ and 10. Cell morphology and cell dimensions were examined using phase-contrast microscopy (Axio Imager; Zeiss). Anaerobic growth was checked on R2A agar medium using a BBL anaerobic jar (Becton Dickinson) at $>15 \% \mathrm{CO}_{2}$. Other physiological properties, carbohydrate assimilation and enzyme activities were tested using API 20NE, API ID 32GN and API ZYM test strips according to instructions of the manufacturer (bioMérieux). The results of the physiological and biochemical tests are given in Table 1 and the species description. 
Table 1. Differential phenotypic characteristics of strain $5516 \mathrm{~T}-20^{\top}, P$. dokdonensis $\mathrm{DS}-8^{\top}$ and $P$. jejuensis KSW2-15

Unless indicated, data are from this study except those for P. dokdonensis DS- $8^{\mathrm{T}}$, which were taken from Yoon et al. (2008). All strains are positive for catalase, for hydrolysis of aesculin, casein, gelatin and starch and for $\beta$-galactosidase, but all are negative for indole production and urease. In API $20 \mathrm{NE}$ and API ID 32GN test strips, all strains assimilate D-glucose, D-mannose, D-mannitol, maltose, potassium gluconate, $N$-acetylglucosamine, malic acid, sucrose, glycogen and melibiose, but do not assimilate L-arabinose, capric acid, trisodium citrate, phenylacetic acid, potassium 5-ketogluconate or potassium 2-ketogluconate. In API ZYM test strips, all strains show positive results for esterase lipase (C8), leucine arylamidase, acid phosphatase, naphthol-AS-BI-phosphohydrolase, $\alpha$-glucosidase and $\beta$-glucosidase, but show negative results for lipase (C14), cystine arylamidase, trypsin, $\beta$ glucuronidase, $N$-acetyl- $\beta$-glucosaminidase and $\alpha$-fucosidase. + , Positive; - , negative; $(+)$, weakly positive; ND, no data available.

\begin{tabular}{|c|c|c|c|}
\hline Characteristic & Strain $5516 \mathrm{~T}-20^{\mathrm{T}}$ & P. jejuensis KSW2-15 & P. dokdonensis DS-8 \\
\hline Isolation source & Air sample & Seaweed & Soil \\
\hline Cell shape & Short rod & Coccus ${ }^{\star}$ & Coccus \\
\hline Oxidase & - & $-{ }^{*}$ & + \\
\hline Nitrate reduction & - & + & - \\
\hline Hydrolysis of DNA & - & $+^{*}$ & ND \\
\hline \multicolumn{4}{|l|}{ Assimilation of: } \\
\hline Adipic acid & - & $(+)$ & - \\
\hline D-Ribose & - & + & - \\
\hline Inositol & - & + & - \\
\hline Sodium acetate & + & + & $\mathrm{ND}$ \\
\hline Lactic acid & - & + & $\mathrm{ND}$ \\
\hline L-Alanine & $(+)$ & - & ND \\
\hline Salicin & + & + & - \\
\hline L-Fucose & + & - & - \\
\hline D-Sorbitol & - & + & - \\
\hline Propionic acid & + & + & ND \\
\hline Valeric acid & + & + & $\mathrm{ND}$ \\
\hline L-Histidine & - & + & $\mathrm{ND}$ \\
\hline 3-Hydroxybutyric acid & + & + & $\mathrm{ND}$ \\
\hline L-Proline & - & + & ND \\
\hline \multicolumn{4}{|l|}{ Enzyme activities } \\
\hline Alkaline phosphatase & - & + & + \\
\hline Esterase $(\mathrm{C} 4)$ & - & + & + \\
\hline Valine arylamidase & - & - & + \\
\hline Cystine arylamidase & - & - & + \\
\hline$\alpha$-Galactosidase & - & + & + \\
\hline$\alpha$-Chymotrypsin & + & - & - \\
\hline$\alpha$-Mannosidase & - & + & $(+)$ \\
\hline DNA G $+C$ content $(\mathrm{mol} \%)$ & 70.5 & $74^{\star}$ & 70.7 \\
\hline
\end{tabular}

${ }^{\star}$ Data taken from Lee (2006).

Sequencing of the 16S rRNA gene was performed as described previously (Kwon et al., 2003). Phylogenetic analysis was performed using the software package MEGA, version 3.1 (Kumar et al., 2004), after multiple alignment of the data by CLUSTAL w (Thompson et al., 1994). Phylogenetic dendrograms were constructed using the neighbour-joining and maximum-parsimony methods with bootstrap percentages based on 1000 replications. A continuous stretch of approximately $1400 \mathrm{bp}$ of strain $5516 \mathrm{~T}-20^{\mathrm{T}}$ was used in the analysis. According to the neighbour-joining tree (Fig. 1), strains $5516 \mathrm{~T}-20^{\mathrm{T}}$, P. dokdonensis $\mathrm{DS}-8^{\mathrm{T}}$ and P. jejuensis KSW2- $15^{\mathrm{T}}$ formed a separate clade within the family Intrasporangiaceae with high bootstrap support (94\%). This branch was also supported by the maximumparsimony tree. The highest levels of sequence similarity between strain $5516 \mathrm{~T}-20^{\mathrm{T}}$ and recognized species were found with respect to the type strains of $P$. dokdonensis and P. jejuensis (97.5 and $96.1 \%$, respectively).

DNA-DNA hybridization was carried out using the filter hybridization method, as described by Seldin \& Dubnau (1985). Probe labelling was conducted using the nonradioactive DIG-High prime system (Roche) and hybridized DNA was visualized using the DIG luminescent detection kit (Roche). DNA-DNA relatedness was quantified using a densitometer (Bio-Rad). The DNA-DNA hybridization value between $5516 \mathrm{~T}-20^{\mathrm{T}}$ and $P$. dokdonensis DS- $8^{\mathrm{T}}$ was $41 \%$.

Chemotaxonomic investigations, i.e. analysis of the peptidoglycan (Schleifer \& Kandler, 1972), polar lipids and 


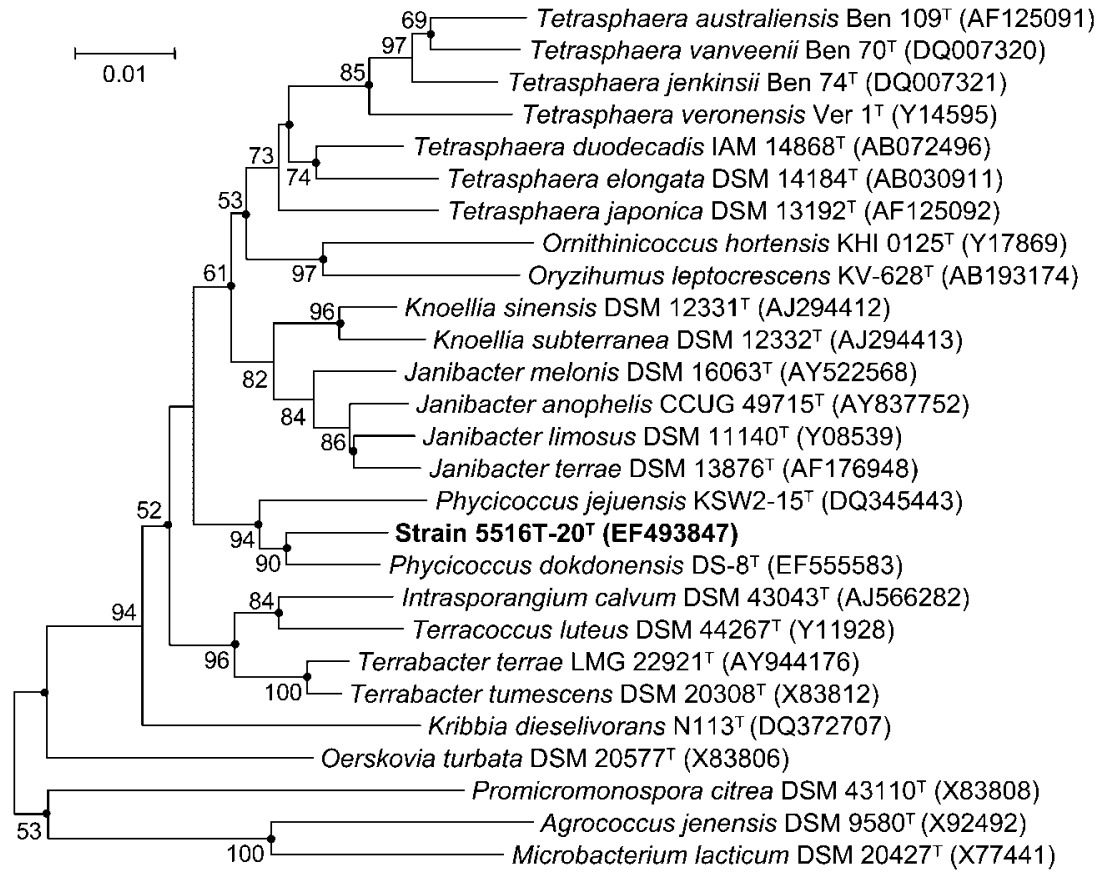

Fig. 1. Neighbour-joining phylogenetic tree, based on almost-complete 16S rRNA gene sequences, showing the position of strain $5516 \mathrm{~T}-20^{\top}$. Numbers at nodes indicate bootstrap percentages (based on 1000 resamplings); only values $>50 \%$ are given. Filled circles indicate that the corresponding branches were also recovered in the maximum-parsimony tree. Bar, 0.01 substitutions per nucleotide position. menaquinones (Minnikin et al., 1984), whole-cell sugars (Staneck \& Roberts, 1974), mycolic acids (Minnikin et al., 1975) and fatty acids (standard protocol of the Sherlock Microbial Identification System; Sasser, 1990), were performed as described previously. DNA G+C contents were determined using an HPLC method (Mesbah et al., 1989). The peptidoglycan of strain $5516 \mathrm{~T}-20^{\mathrm{T}}$ contained meso-diaminopimelic acid, alanine and glutamic acid, i.e. it was of the $\mathrm{A} 1 \gamma$ (A31) type according to the catalogue of strains of the Deutsche Sammlung von Mikroorganismen und Zellkulturen (Braunschweig, Germany) (DSMZ, 2001). Phosphatidylethanolamine, phosphatidylinositol and diphosphatidylglycerol were present in the phospholipid profiles. Strain $5516 \mathrm{~T}-20^{\mathrm{T}}$ contained MK-8 $\left(\mathrm{H}_{4}\right)$ as the predominant menaquinone. Glucose and ribose were detected as whole-cell sugars. No mycolic acids were detected in the cell wall. The major fatty acids of strain $5516 \mathrm{~T}-20^{\mathrm{T}}$ were $\mathrm{C}_{17: 1} \omega 8 c(18.6 \%)$, iso- $\mathrm{C}_{15: 0}(15.7 \%)$, iso$\mathrm{C}_{16: 0}(14.6 \%)$ and $\mathrm{C}_{17: 0}(9.4 \%)$. More detailed fatty acid profiles of strains tested in this study are given in Supplementary Table S1 (available in IJSEM Online). The $\mathrm{G}+\mathrm{C}$ content of the DNA from strain $5516 \mathrm{~T}-20^{\mathrm{T}}$ was $70.5 \mathrm{~mol} \%$.

Phylogenetically, strain $5516 \mathrm{~T}-20^{\mathrm{T}}$ formed a robust cluster with $P$. dokdonensis DS- $8^{\mathrm{T}}$ and $P$. jejuensis KSW2 $-15^{\mathrm{T}}$ that was separable from recognized members of the family Intrasporangiaceae (Fig. 1). The menaquinone content and the diagnostic amino acid of the cell-wall peptidoglycan are in agreement with the description of the genus Phycicoccus. The major fatty acid profiles were similar, although there was variation with respect to some components among strains (Supplementary Table S1). In terms of species demarcation, strain $5516 \mathrm{~T}-20^{\mathrm{T}}$ showed a relatively low level of DNA-DNA hybridization (41\%) with respect to $P$. dokdonensis $\mathrm{DS}-\mathrm{8}^{\mathrm{T}}$, confirming that the isolate represented a separate genomic species within the genus Phycicoccus (Wayne et al., 1987). In addition, strain 5516T-20 ${ }^{\mathrm{T}}, P$. jejuensis KSW2 $-15^{\mathrm{T}}$ and $P$. dokdonensis DS- $8^{\mathrm{T}}$ differed from each other in terms of several phenotypic characteristics (Table 1). On the basis of the data presented, therefore, strain $5516 \mathrm{~T}-20^{\mathrm{T}}$ represents a novel species of the genus Phycicoccus, for which the name Phycicoccus aerophilus sp. nov. is proposed.

\section{Description of Phycicoccus aerophilus sp. nov.}

Phycicoccus aerophilus (ae.ro.phi'lus. Gr. n. aer air; Gr. adj. philos loving; N.L. masc. adj. aerophilus air-loving).

Cells are strictly aerobic, Gram-positive, non-spore-forming, short rods $(0.8-0.9 \times 1.1-1.5 \mu \mathrm{m})$. Colonies are white, round and convex with clear margins on R2A medium. Growth is observed at $5-37{ }^{\circ} \mathrm{C}$ (optimally at $30{ }^{\circ} \mathrm{C}$ ), $\mathrm{pH} 5-$ 9 (optimally at $\mathrm{pH} 6-7$ ) and $0-7 \% \mathrm{NaCl}(\mathrm{w} / \mathrm{v})$. Hydrolyses casein, starch, Tween 80, tyrosine and xanthine, but does not hydrolyse chitin, CM-cellulose, hypoxanthine or pectin. Positive for hydrolysis of aesculin and gelatin and for $\beta$-galactosidase, but negative for nitrate reduction, indole production, glucose fermentation, arginine dihydrolase and urease (API 20NE test strip). Assimilates Dglucose, D-mannose, D-mannitol, $N$-acetylglucosamine, potassium gluconate, malic acid, sucrose, sodium acetate, glycogen, salicin, melibiose, L-fucose, propionic acid, valeric acid and 3-hydroxybutyric acid. Weakly assimilates L-alanine. Does not assimilate L-arabinose, capric acid, adipic acid, trisodium citrate, phenylacetic acid, L-rhamnose, D-ribose, inositol, itaconic acid, suberic acid, sodium 
malonate, lactic acid, potassium 5-ketogluconate, 3-hydroxybenzoic acid, D-sorbitol, L-histidine, potassium 2-ketogluconate, 4-hydroxybenzoic acid or L-proline (API 20NE and API ID 32GN test strips). The diagnostic cell-wall diamino acid is meso-diaminopimelic acid and the peptidoglycan type is $\mathrm{A} 1 \gamma$. The whole-cell sugars are glucose and ribose. The polar lipids comprise phosphatidylethanolamine, phosphatidylinositol and diphosphatidylglycerol. The predominant fatty acids are $\mathrm{C}_{17: 1} \omega 8 c$, iso- $\mathrm{C}_{15: 0}$, iso- $\mathrm{C}_{16: 0}$ and $\mathrm{C}_{17: 0}$. The major menaquinone is MK- $8\left(\mathrm{H}_{4}\right)$. The DNA $\mathrm{G}+\mathrm{C}$ content of the type strain is $70.5 \mathrm{~mol} \%$.

The type strain, 5516T-20 ${ }^{\mathrm{T}} \quad\left(=\mathrm{KACC} 20658^{\mathrm{T}}=\mathrm{DSM}\right.$ $\left.18548^{\mathrm{T}}\right)$, was isolated from air sampled in Taean, Republic of Korea.

\section{Acknowledgements}

This study was supported by a programme of international collaborative research (NIAB grant no. 06-4-11-19-3) between the Rural Development Administration (Suwon, Republic of Korea) and the DSMZ (Braunschweig, Germany).

\section{References}

DSMZ (2001). Catalogue of Strains, 7th edn. Braunschweig: Deutsche Sammlung von Mikroorganismen und Zellkulturen.

Kumar, S., Tamura, K. \& Nei, M. (2004). MEGA3: integrated software for molecular evolutionary genetics analysis and sequence alignment. Brief Bioinform 5, 150-163.

Kwon, S. W., Kim, J. S., Park, I. C., Yoon, S. H., Park, D. H., Lim, C. K. \& Go, S. J. (2003). Pseudomonas koreensis sp. nov., Pseudomonas umsongensis sp. nov. and Pseudomonas jinjuensis sp. nov., novel species from farm soils in Korea. Int J Syst Evol Microbiol 53, 21-27.

Lee, S. D. (2006). Phycicoccus jejuensis gen. nov., sp. nov., an actinomycete isolated from seaweed. Int J Syst Evol Microbiol 56, 2369-2373.
Mesbah, M., Premachandran, U. \& Whitman, W. B. (1989). Precise measurement of the $\mathrm{G}+\mathrm{C}$ content of deoxyribonucleic acid by highperformance liquid chromatography. Int J Syst Bacteriol 39, 159-167.

Minnikin, D. E., Alshamaony, L. \& Goodfellow, M. (1975). Differentiation of Mycobacterium, Nocardia, and related taxa by thin-layer chromatographic analysis of whole-organism methanolysates. J Gen Microbiol 88, 200-204.

Minnikin, D. E., O'Donnell, A. G., Goodfellow, M., Alderson, G., Athalye, M., Schaal, A. \& Parlett, J. H. (1984). An integrated procedure for the extraction of bacterial isoprenoid quinones and polar lipids. J Microbiol Methods 2, 233-241.

Sasser, M. (1990). Identification of bacteria by gas chromatography of cellular fatty acids, MIDI Technical Note 101. Newark, DE: MIDI Inc.

Schleifer, K. H. \& Kandler, O. (1972). Peptidoglycan types of bacterial cell walls and their taxonomic implications. Bacteriol Rev 36, 407-477.

Seldin, L. \& Dubnau, D. (1985). Deoxyribonucleic acid homology among Bacillus polymyxa, Bacillus macerans, Bacillus azotofixans, and other nitrogen-fixing Bacillus strains. Int J Syst Bacteriol 35, 151-154.

Smibert, R. M. \& Krieg, N. R. (1994). Phenotypic characterization. In Methods for General and Molecular Bacteriology, pp. 607-654. Edited by P. Gerhardt, R. G. E. Murray, W. A. Wood \& N. R. Krieg. Washington, DC: American Society for Microbiology.

Stackebrandt, E., Rainey, F. A. \& Ward-Rainey, N. L. (1997). Proposal for a new hierarchic classification system, Actinobacteria classis nov. Int J Syst Bacteriol 47, 479-491.

Staneck, J. L. \& Roberts, G. D. (1974). Simplified approach to identification of aerobic actinomycetes by thin-layer chromatography. Appl Microbiol 28, 226-231.

Thompson, J. D., Higgins, D. G. \& Gibson, T. J. (1994). Clustal W: improving the sensitivity of progressive multiple sequence alignment through sequence weighting, position-specific gap penalties and weight matrix choice. Nucleic Acids Res 22, 4673-4680.

Wayne, L. G., Brenner, D. J., Colwell, R. R., Grimont, P. A. D., Kandler, O., Krichevsky, M. I., Moore, L. H., Moore, W. E. C., Murray, R. G. E. \& other authors (1987). International Committee on Systematic Bacteriology. Report of the ad hoc committee on reconciliation of approaches to bacterial systematics. Int J Syst Bacteriol 37, 463-464.

Yoon, J.-H., Lee, S.-Y., Kang, S.-J. \& Oh, T.-K. (2008). Phycicoccus dokdonensis sp. nov., isolated from soil. Int J Syst Evol Microbiol 58, 597-600. 